\title{
A qualitative report on exploratory data on the possible emotional/behavioral correlates of Covid-19 lockdown in 4-10 years children in Italy.
}

Luca Pisano ${ }^{1}$, Domenico Galimi², Luca Cerniglia ${ }^{3}$

${ }^{1}$ IFOS - Center for the Family, Childhood and Adolescent Section Stress, Trauma and Psychological Support for COVID Emergency 19

${ }^{2}$ University of London

${ }^{3}$ International Telematic University Uninettuno

Acknowledgements:

We thank the 6510 parents who compiled the questionnaire. The colleagues from Sardinia Observatory of Cybercrime, the network of Digital Parents and Schools' Digital Committees. Healthcare operators and social services, headmasters and teachers of several Sardinian schools. Lastly, IFOS collaborators: Pierpaolo Mascia (for the statistics), Paolo Fanti e Adriano Mangoni (for having revised the manuscript), Domenico Galimi for having edited the English translation, Roberta Picciau for having kept in touch with parents and press and Carla Sanjust for having taken care of the graphics compartment.

Conflict of interest: the authors declare no conflict of interest.

The study received no specific funds.

Important Caveat: This report is intended as a preliminary work aimed at raising public debate on the topic of psychological consequences of Covid-19 lockdown in children. Results are exploratory and conclusions are speculative and must be confirmed through further rigorous studies. 


\section{Introduction}

The Pandemic Disease

For the past four weeks, we have been living, an unprecedented event in the history of the Republic of Italy. The nation had never been fully quarantined. The impact of these measures on people's lives has been sudden and unexpected, due to how quickly the disease spread in Northern Italy at first, and then in the rest of the country. Other European countries have been following the Italian example imposing restrictions on individual freedoms to protect public health. Considering the present historical moment adults, adolescents and children who, until recently had a normal lifestyle, need to accept restriction imposed by the governments and confront themselves with a potentially distressing series of events which interrupted their usual life style.

On December 31, 2019 a series of pneumonia cases was reported in Wuhan, in the province of Hubei, in China. On January 9, 2020 the Chinese Centre for Disease Control and Prevention ${ }^{1}$ reported a new coronavirus, the COVID 19, as carrier of this disease. At the end of February, the highest amount of cases reported was found in China. However, infections in EU countries and in the UK kept growing. On March 5 the Italian Government decreed the shutdown of Italian schools and, through successive decrees, the state of quarantine. On March 11, 2020118.598 cases of COVID-19 were recorded worldwide and the WHO Director declared a global pandemic ${ }^{2}$. Therefore, all nations on the planet have been applying the procedure was used it was in 1127 in Venice in order to stop leprosy. After that, quarantine was once again used 300 years later in the UK in order to face the plague (Newman, 2012 ${ }^{3}$ ). Quarantine has also been used in recent times, for example, during the 2003 SARS epidemic, a number of Chinese and Canadian cities were put in lockdown, and similarly to that several regions of West Africa in occasion of the Ebola epidemic of 2014 (Wang, Zhang, Zhao, Zhang \& Jiang, 20204).

The impact of the pandemic on millions of children, adolescents and families is currently evaluated in hundreds of studies worldwide although the presence of this issue in public debate is not prevalent. On the other hand, research strives to find feasible recruitment and assessment methods in this moment, due to the fact that people are not directly contactable, validated measures purposely created have not been published, and youths' emotional/behavioral functioning is not observable. For these reasons, we considered appropriate to employ the same instruments used in case of natural disasters such as hurricanes, earthquakes, tsunami, and epidemics. However, characteristics and impact of these catastrophic events are not fully compatible with the COVID-19 pandemic.

During this quarantine phase, the only reliable and easy-to-use instrument is an online questionnaire, a valid option as long as:

\footnotetext{
${ }^{1}$ http://www.chinacdc.cn/en/

2 https://www.ecdc.europa.eu/sites/default/files/documents/RRA-sixth-update-Outbreak-of-no- vel-coronavirus-disease2019-COVID-19.pdf

${ }^{3}$ Newman K. (2012). Shutt up: Bubonic plague and quarantine in early modern England. J Sol Hist 2012; 45: 809-34.

${ }^{4}$ Wang G., Zhang Y., Zhao J., Zhang J., Jiang F. (2020). Mitigate the effects of home confinement on children during the COVID-19 outbreak. Lancet. Volume 395, issue 10228, p945-947, March 21, 2020.
} 
- there is significant control on how the sample is formed (Riva, Teruzzi \& Anolli, $2004^{5}$ );

- a questionnaire is built, whose reliability is attested not only by standard multiple factors, but also by providing a high number of options which allows to measure variables accurately.

However, in the present historical moment, such limitations are not easily overcome. It would be quite difficult, due to quarantine restrictions, to build and validate in a short time the instrument of the research, by screening out telephonically, and afterwards online, a population sample made of thousands of Sardinian parents available to participate the research, only asking afterwards to answer a long questionnaire.

Measuring children's reaction to the pandemic, in a historical moment in which parents and children spend the entire day together, is even more complicated because family dynamics tend to exacerbate themselves and they do not help the purposes of research.

Evaluating ex-post the effect of a biological disaster is never easy. The outcomes of potentially distressing situations, even in case of natural disasters (Alvarez \& Hunt, $2005^{6}$ ) are co-determined by the interaction of several factors including: the parents' psychological response to the pandemic, which influences the children's reaction; mental and physical well-being of parents and children before the event; quality of interactions between parents and children before enduring the pandemic and, lastly, resilience, in coping with adversities.

For all the above reasons, it has not been possible to employ a more rigorous approach and the results displayed here, despite the extensiveness of the sample, are not statistically significant. However, this data offers an interesting view of the present situation and, while studying the phenomenon will absolutely require more research, it is quite useful to offer families points of reflection in order to provide better care for their children.

\section{Natural Disasters and Distress}

Natural disasters are generally split in three main types ${ }^{7}:$ 1) weather-related (flooding, storms, extreme temperatures); 2) geophysics-related (earthquake, tsunami, volcanic eruption); 3) biology-related (epidemics, infestation).

Like other natural disasters, biological disasters happen suddenly and their effects, which last for a prolonged time, involve several consequences in the short and long term. Scientific Research (Breslau, 2001 ${ }^{8}$ ) highlights how being exposed to natural disasters is

\footnotetext{
${ }^{5}$ Riva G., Teruzzi T., Anolli L. (2004). The Use of the Internet in Psychological Research: Comparison of Online and Offline Questionnaires. CyberPsychology \& BehaviorVol. 6, No. 1 Original Articles. Published Online:5 Jul 2004

${ }^{6}$ Alvarez J., Hunt M. (2005). Risk and resilience in canine search and rescue handlers after 9/11. Trauma Stress 2005; 18: 497-505.

${ }^{7}$ OFDA/CRED International Disasters data Base (EM-DAT). (2006). Disaster statistics 1991- 2005. Retrived on July 26, from http://www.unisdr.org/disaster-statistics/introduction.htm

${ }^{8}$ Breslau N. (2001). The epidemiology of posttraumatic stress disorder: what is the extent of the problem? J Clin Psychiatry 2001; 62 (suppl 17): 16-22.
} 
related to a greater risk of developing mental health issues, including post-traumatic stress disorder (PTSD), depression, anxiety, sleep disorders or substance abuse.

Concerning the specific case of coronavirus pandemic, according to Satcher and Kenned $\left(2020^{\circ}\right)$, an increase in levels of fear and anxiety is usually the tip of the iceberg if considering further implication for mental health. A poll carried out among Hong Kong residents about the SARS, quoted by Satcher (2020), showed how up to $2 / 3$ of interviewees expressed feelings of impotency, half of them stated how their mental health deteriorated moderately or significantly due to the epidemic and $16 \%$ displayed psychological symptoms. The generalised feeling was of their own life being in danger and the mental disorders caused by the illness or by losing loved ones were the most prominent detected mental health issues.

A study recently published by the journal Lancet, by Brooks $\left(2020^{10}\right)$ et al., after having consulted three electronic databases with the purpose of studying the psychological impact of quarantine, selected 24 amongst the 3166 available articles. This research, carried out in 10 countries, involved individuals affected by SARS, Ebola, H1N1 flu 20092010, Middle East Respiratory Syndrome and the equine influence. One of said studies involved both H1N1 and SARS. Researchers discovered how the psychological impact of quarantine may be significantly serious and cause a series of psychological issues including anxiety, anger, children, sleep disorders, depression and, in the most serious cases, PTSD. Stress factors were generally associated with duration of quarantine measures (Hawryluck, Gold, Robinson, Pogorski, Galea \& Styra, 2004 ${ }^{11}$; Reynolds, Garay, Deadmon, Moran, Gold \& Styra, 2008 ${ }^{12}$ ), fear of being infected (Bai, Lin, Lin, Chen, Chue, Chou, $2004^{13}$ ), frustration and boredom (Cava, Fay, Beanlands, McCay \& Wingall, $2005^{14}$ ) and inadequate information (DiGiovanni, Conley, Chiu \& Zaborski, $2004^{15}$ ), while the main post-quarantine stressors were identified as financial losses (Mihashi, Otsubo, Yinjuan, Nagatomi, Hoshiko \& Ishitake, 2009 ${ }^{16}$ ) and stigma (Wester \& Giesecke, 2019 ${ }^{17}$ ).

\footnotetext{
${ }^{9}$ Satcher D., Kenned P.J. (2020). Failure to address coronavirus mental health issues will prolong impact. https://thehill.com/opinion/healthcare/488370-failure-to-address-coronavirus- mental-health-issues-will-prolong-impact
}

10 Brooks S.K., Webster R.K., Smith L.E., Woodland L., Wessely S., Greenberg N., Rubin G. (2020). The psychological impact of quarantine and how to reduce it: rapid review of the evidence. Lancet 2020; 395: 912-20. Published Online February 26, 2020 https://doi.org/10.1016/ S0140-6736(20)30460-8

${ }^{11}$ Hawryluck L., Gold WL., Robinson S., Pogorski S., Galea S., Styra R. (2004). SARS control and psychological effects of quarantine Toronto, Canada. Emerg Infect Dis 2004; 10: 1206-12.

12 Reynolds D.L., Garay J.R., Deamond S.L., Moran M.K., Gold W., Styra R. (2008). Understanding, compliance and psychological impact of the SARS quarantine experience. Epidemiol Infect 2008; 136: 997-1007.

${ }^{13}$ Bai Y., Lin C.C., Lin C.Y., Chen J.Y., Chue C.M., Chou P. (2004). Survey of stress reactions among health care workers involved with the SARS outbreak. Psychiatr Serv 2004; 55: 1055-57.

${ }^{14}$ Cava M.A., Fay K.E., Beanlands H.J., McCay E.A., Wignall R. (2005). The experience of quarantine for individuals affected by SARS in Tor perimetro stazioneonto. Public Health Nurs 2005; 22: 398-406.

${ }^{15}$ DiGiovanni C., Conley J., Chiu D., Zaborski J. (2004). Factors influencing compliance with quarantine in Toronto during the 2003 SARS outbreak. Biosecur Bioterror 2004; 2: 265-72.

\footnotetext{
${ }^{16}$ Mihashi M., Otsubo Y., Yinjuan X., Nagatomi K., Hoshiko M., Ishitake T. (2009). Predictive factors of psychological disorder development during recovery following SARS outbreak. Health Psychol 2009; 28: 91-100.

${ }^{17}$ Wester M., Giesecke J. (2019). Ebola and healthcare worker stigma. Scand J Public Health 2019; Mar 47: 99-104.
} 
Concerning children, any disease-containment measure, including quarantine and isolation, may cause distressing effects. Sprang e Silman $\left(2013^{18}\right)$, while studying psychosocial answers by children and parents to pandemic disasters, highlighted how average scores of PSTD where four times higher in children subjected to quarantine measures if compared to those who had not. A mixed approach was employed (questionnaires, focus groups and interviews) involving 398 parents.

Dyb, Jensen e Nygaard $\left(2011^{19}\right)$, as part of a study on the effects caused by the 2004 tsunami in Southeast Asia, detected how PSTD reactions in parents significantly predicted PSTD reactions in their children. Their research involved parents of 319 Norwegian children and teenagers aged between 6 and 18, who reported the psychological effects of the tsunami on their children's lives.

As specified in the preamble, individual answers to potentially distressing events may be influenced by both risk and prevention factors (Maj, Starace, Crepet, Lobrace, Veltro, De Marco et al., $1989^{20}$ ) interacting with each other in a probabilistic way. The individual meaning attributed to an event is the product of a complex interaction between the event, personal history, temperament, coping strategies, future expectations and biological factors: these factors combine with each other and the result is the impact of the event on psychological functioning and quality of life of involved subjects (Pollice, Bianchini, Roncone \& Casacchi, 2012 21 ). The degree of psychological distress is related to individual, family and social risk factors existing before (Farinaro, Jossa \& Trevisan, $1996^{22}$ ) rather than being merely related to the traits of distressing stimulus. For a large majority of individuals psychological symptoms are usually transitory and acute episodes ${ }^{23}$ (Sherin \& Nemeroff, 2011 ${ }^{24}$; Lanius, Vermetten, Loewenstein, Brand, Schmahl, Bremner et al., $\left.2010^{25}\right)$.

\footnotetext{
${ }^{18}$ Sprang G., Silman M. (2013). Posttraumatic stress disorder in parents and youth after health-related disasters. Disaster Med Public Health Prep 2013; 7: 105-10.

${ }^{19}$ Dyb G., Jensen T.K., Nygaard E. (2011). Children's and Parents' Posttraumatic Stress Reactions After the 2004 Tsunami. Child Psychol Psychiatry. Oct 16(4) 621-34 Oct 2011.

${ }^{20}$ Maj M., Starace F., Crepet P., Lobrace S., Veltro F., De Marco F., Kemali D. (1989). Prevalence of psychiatric disorders among subjects exposed to a natural disaster. Acta Psychiatr Scand 1989; 79: 544-9.

${ }^{21}$ Pollice R., Bianchini V., Roncone R., Casacchi M. (2012). Distress psicologico e disturbo post-traumatico da stress (DPTS) in una popolazione di giovani sopravvissuti al terremoto dell'Aquila. Riv_Psichiatr 2012;47(1):59-64
}

22 . Bland S.H., O'Leary E.S., Farinaro E., Jossa F., Trevisan M. (1996). Long-term psychological effects of natural disasters. Psychosom Med 1996; 58: 18-24.

23 Maxi emergenza nelle calamità e trauma psichico, presso Palazzina accoglienza Ospedale San Gerardo - Aula Enrico Maria Pogliani Via Pergolesi 33 - Monza. Sabato 27 maggio 2017.

https://www.omceomb.it/sites/default/files/OMCEOMB/AttiConvegni/2017_maggio27_ConvEmergenza_Abs.pdf

24 Sherin J.E., Nemeroff C.B. (2011). Post-traumatic stress disorder: the neurobiological impact of psychological trauma. Dialogues Clin Neurosci 13 (3):263-78.

25 . Modulation in PTSD: Clinical and Neurobiological Evidence for a Dissociative Subtype. Am J Psychiatry. 2010 Jun; 167(6): 640-647. 
Based on the theoretical and empirical premises illustrated above, the research aimed to explore the emotional/behavioral responses of children from 4 to 10 years of age exposed to the (potentially distressing) situation of the Covid-19 pandemic, based on their parents' assessment, with the specific objective of creating a qualitative descriptive report.

\section{Method}

To conduct the survey, an ad-hoc questionnaire was constructed, divided into three areas, four questions per area, encompassing a total of twelve questions. The areas that constitute the tool were identified on the basis of previous literature on children's responses to potentially distressing situations (Dehon \& Scheeringa, 2006 ${ }^{26}$; Cohen, Kelleher \& Mannarino, $2008^{27}$ ).

The first area investigated the regressive behavior of children with particular reference to the loss of some developmental skills previously achieved (e.g. sleeping alone in their own room, sphincter control limited to enuresis, adequacy of language, emotion regulation).

(item examples: Has your son/daughter asked to sleep in his/her parents' bed in the last week? Has your son/daughter been wetting the bed again in the last week?). The second area explored the child's opposing behavior against the sudden change in lifestyle: irritability, constant mood swings, sleep disorders and nervousness about restrictions and messages coming from TV or parents about the pandemic (item examples: In the last week, did your child show more irritability? Over the last week, has your son/daughter experienced any mood swings that you hadn't noticed before?). Finally, the third area investigated the adaptation behavior of the children with reference to calmness, tranquility, balance, and adaptation to restrictions, the manifestation of listlessness towards the activities they were carrying out before the pandemic (item examples: In the last week, has your son seemed calmer and calmer to you? Did your son seem wiser and more thoughtful in the last week?).

\section{Sample}

The questionnaire was administered to parents living in Sardinia (Italy) who have children aged between 4 and 10 years. The participants were guaranteed anonymity and the study was conducted according to the recommendations of the Helsinki Declaration.

It was decided to focus attention on the emotional/behavioral responses of children in this age group because, starting from the age of 4, important developmental touch-points have been usually reached (sphincter control, emotional self-regulation, falling asleep in one's own room, etc.) and it is therefore possible to assess both regressions in the acquired abilities and the strategies implemented by the child to cope with potentially disorganizing situations (Rice \& Groves, $2005^{28}$ ). On the other hand, after the age of 10 , we generally witness the emergence of pre-adolescence developmental phase, which allows a series of physical and emotional changes that reorganize the emotional experience of children, their relationship with attachment figures and behavioral responses to stress. These changes

\footnotetext{
${ }^{26}$ Dehon C., Scheeringa M.S. (2006). Screening for preschool posttraumatic stress disorder with the Child Behavior Checklist. Journal of Pediatric Psychology, 31(4), 431- 435.

${ }^{27}$ Cohen, J.A., Kelleher K.J., Mannarino A.P. (2008). Identifying, treating, and referring traumatized children: The role of pediatric providers. Archives of Pediatrics and Adolescent Medicine, 162(5), 447-452.
}

28 . Rice K.F., Groves B.M. (2005). Hope and healing: A caregiver's guide to helping young children affected by trauma. Washington, D.C.: Zero to Three Press. 
are also associated with the increased maturation of the frontal cortex that consents more abstract reasoning and the ability to moderate impulsive behavior (Gieed, $2012^{29}$ ).

The link to access the online questionnaire, built through the drive.google ${ }^{30}$ forms, was forwarded via email and Whatsapp to lists of social health professionals, teachers and parents and then published on the Facebook page https://www.facebook.com/LucaPisanolFOS. It was active from Saturday 21st March at 10.00 a.m. to Tuesday 24th March 2020 at 06.50 a.m. 6510 questionnaires were filled out. The analysis of the distribution of the sample in relation to the age group allowed to admit 5989 completed questionnaires (Tab. A). No information was collected about the child's gender (M/F).

Tab. A. Questionnaire distribution per age range.

\begin{tabular}{|l|l|l|}
\hline $\begin{array}{l}\text { Age groups accepted for the } \\
\text { research }\end{array}$ & $\begin{array}{l}\mathbf{N}^{\circ} \text { of completed } \\
\text { questionnaires }\end{array}$ & $\mathbf{F}$ \\
\hline 4 & 920 & $\mathbf{1 5 , 3 6 \%}$ \\
\hline 5 & 869 & $\mathbf{1 4 , 5 1 \%}$ \\
\hline 6 & 857 & $\mathbf{1 4 , 3 1 \%}$ \\
\hline 7 & 794 & $\mathbf{1 3 , 2 5 \%}$ \\
\hline 8 & 895 & $\mathbf{1 4 , 9 5 \%}$ \\
\hline 9 & 908 & $\mathbf{1 5 , 1 6 \%}$ \\
\hline 10 & 746 & $\mathbf{1 2 , 4 6 \%}$ \\
\hline TOTAL & $\mathbf{5 9 8 9}$ & \\
\hline & & \\
\hline $\begin{array}{l}\text { Age groups not accepted for } \\
\text { the research }\end{array}$ & & \\
\hline 1 & 21 & $4,03 \%$ \\
\hline 2 & 39 & $7,48 \%$ \\
\hline 3 & 192 & $36,85 \%$ \\
\hline 11 & 170 & $32,63 \%$ \\
\hline 12 & 50 & $9,60 \%$ \\
\hline 13 & 28 & $5,37 \%$ \\
\hline 14 & 9 & $1,73 \%$ \\
\hline 15 & 6 & $1,15 \%$ \\
\hline 16 & 3 & $0,57 \%$ \\
\hline 17 & 1 & $0,20 \%$ \\
\hline 55 & 1 & $0,20 \%$ \\
\hline 864 & 1 & $0,20 \%$ \\
\hline TOTAL & $\mathbf{5 2 1}$ & \\
\hline TOTAL aggregated & $\mathbf{6 5 1 0}$ & \\
\hline
\end{tabular}

Note: the age groups not admitted to the research concern those outside the 4-10 years old range, both for those questionnaires that are validly filled in and those that are incompletely or incorrectly filled in.

\footnotetext{
${ }^{29}$ Giedd J.N. (2012). The digital revolution and adolescent brain evolution. The Journal of adolescent health: official publication of the Society for Adolescent Medicine, 51(2), 101-105.https:// doi.org/10.1016/j.jadohealth.2012.06.002

30 https://docs.google.com/forms/d/e/1FAlpQLSc3fuKFiKNusuV6IF54pPNWaG1SdYHxj63BsU hIJkeOILQA/viewform?usp=sf_link
} 


\section{Results}

As regards the manifestation of regressive behavior, it was found that:

1) $26.48 \%$ of children, who before the Covid-19 emergency had acquired the competence to sleep alone in their own bedroom, asked to sleep in their parents' bed (Tab. 1 and Graph.1). The most representative age of the problem was 4 years (16.58\%);

2) $2.84 \%$ started suffering from enuresis (Tab. 2 and Graph. 2). The symptom manifested itself more at $4(29.41 \%), 5(25.29 \%)$ and 6 years of age $(15.29 \%)$ and then decreased with increasing age;

3) $5.48 \%$ showed a general worsening of their vocabulary (Tab. 3 and Graph. 3 ). Even in this case, the problem was particularly evident in the age group ranging 4-6 years, specifically: 4 years (20.73\%), 5 years $(14.33 \%)$ and 6 years $(15.55 \%)$;

4) $18.17 \%$ began to express fears they didn't have before. In relation to age, no percentage differences were found.

With regard to the manifestation of oppositive behavior for the sudden change in daily routines, our results showed that:

5) $53.53 \%$ of children showed increased irritability, intolerance to rules, whims and excessive demands. (Tab. 5 and Graph. 5). The age group most exposed to the problem was composed of 4-6 years old children, specifically: 4 years old (18.31\%), 5 years old $(16.16 \%)$ and 6 years old (14.66\%), decreasing with increasing age;

6) $21.17 \%$ showed continuous mood swings (Tab. 6 and Graph. 6). The symptoms became more frequent at $4(18.06 \%)$ and $8(15.30 \%)$;

7) $19.99 \%$ experienced sleep problems: difficulty falling asleep, restlessness, frequent awakenings. (Tab. 7 and Graph. 7). Even in this case the problem was more frequent at 4 $(15.71 \%)$ and $8(16.04 \%)$.

8) $34.26 \%$ were nervous about the pandemic when watching TV talk-shows about the coronavirus or because of restrictions. (Tab. 8 and Graph. 8). The symptom became more frequent at $8(17.01 \%)$ and $9(17.40 \%)$.

With regards to the manifestation of adaptive behaviors of calmness, balance, adaptation to restrictions and the manifestation of listlessness towards the activities children were carrying out before the pandemic, it emerged that:

1) $31.38 \%$ of the children seemed calmer during the emergency than before it (Table 9 and Graph. 9). The most representative age group was 8-9 years (16.42\%), 9 years $(16.84 \%)$

2) $49.57 \%$ seemed wiser and more thoughtful (Table 10 and Graph. 10). The most representative age group was 8-9 years old. Specifically, 8 years $(15.46 \%)$, 9 years $(16.37 \%)$;

3) $92.57 \%$ seemed able to adapt to the pandemic restrictions (Table 11 and Graph. 11). The adaptation occurred mainly at $4(15.03 \%)$ and 9 years $(15.17 \%)$;

4) $43.26 \%$ seemed more listless to the activities they were doing before the pandemic, including playing, studying, gaming, etc. (Tab. 12 and Graph. 12). The symptom appeared significantly in the $8-10$-year age group, specifically 8 years $(16.36 \%), 9$ years $(15.82 \%)$ and 10 years $(15.05 \%)$. 


\section{Discussion}

Our preliminary data suggest that during the first month of quarantine (schools have been closed since March 05 and the possibility of leaving home has been progressively limited since March 08), the pandemic had an important effect on children's emotions and behavior.

One in four children (26.48\%) showed the regressive symptom of the demand for physical proximity to their parents during the night and almost one in five $(18.17 \%)$ manifested fears that they never had before. Half of the children $(53.53 \%)$ showed increased irritability, intolerance to rules, whims and excessive demands, and one in five presented mood changes $(21.17 \%)$ and sleep problems including difficulty falling asleep, agitation, and frequent waking up (19.99\%). One in three (34.26\%) displayed nervousness about the topic of pandemic when it was mentioned at home or on TV. Almost one in three $(31.38 \%)$ seemed calmer and one in two (49.57\%) seemed wiser and more thoughtful. Almost all $(92.57 \%)$ seemed able to adapt to the pandemic restrictions; even though one in two $(43.26 \%)$ seemed more listless to the activities they were used to perform before the pandemic including playing, studying, and gaming.

Particular attention must be paid to adaptive behavior showed by some children that could hide the presence of (even if sub-threshold) depressive symptoms or psychological unease (Ammaniti \& Cerniglia, 201931).

In fact, we should consider that: 1) the number of children who seemed able to adapt to the restrictions caused by the pandemic was $5543(92.57 \%)$ and that of these 2842 showed greater irritability, it appears that $51.27 \%$ of children who adapted also showed greater irritability, intolerance to the rules, whims and excessive demands. If adaptation had been a sign of resilience (individual child and/or family), there would not have been any symptoms of protest at the abrupt disruption of lifestyle; 2) many of the children who have adapted to the pandemic and have more irritability, also showed regressive symptoms such as the request to sleep in their parents' bed ( $N=912,32.09 \%)$. 3) many of the children who seemed to have adapted to the pandemic and have more irritability, also showed listlessness to the activities they were undertaking before the pandemic including playing, studying, gaming, etc. $(1603,56.40 \%)$,

Thus, we can then speculate that observed children's adaptive behavior could be a cue for their psychological distress. In fact, one in two children $(51.27 \%)$ who seemed to be adapted to the pandemic also showed greater irritability, intolerance to the rules, whims and excessive demands. One in three (32.09\%) who adapted to the pandemic and had more irritability also showed regressive symptoms, such as the request to sleep in their parents' bed. One in two who has adapted to the pandemic and has greater irritability also shows listlessness with regards to the activities he was doing before the pandemic.

This hypothesis appears also confirmed by the presence of symptoms of fear that before the pandemic had never occurred in $16.99 \%$ of children who were able to adapt. In fact, if we consider that the children adapted to the restrictions caused by the pandemic were $5543(92.6 \%)$ and that of these 942 have begun to manifest fears that they did not have before, it emerges that almost one in six children who appear adapted, manifest fears and therefore psychological distress.

\footnotetext{
${ }^{31}$ Ammaniti M., Cerniglia L. (2019). I passi della crescita. La sicurezza degli affetti e dei legami. GEDI, Roma.
} 


\section{Limits}

The task of scientific research aimed at investigating the personal and social aspects of everyday life is to collect and then interpret the data to respond to certain problems or aspects that society and its components manifest. Particular attention must then be paid to the respect of the scientific method, which consists in the collection of empirical evidence through experimental observation and the formulation of hypotheses and theories that must be subjected to repeated assessments to test their effectiveness. The transparency of the procedures followed and the techniques used both in the evaluation phase and in the data analysis is considered an essential criterion for the recognition of the scientific validity, because it guarantees the controllability and replicability of the research; these are essential elements to effectively achieve the validation of the results obtained and shared with the scientific community (Palumbo \& Garbarino, 2006 ${ }^{32}$ ).

Given that each scientific study makes an important reduction in the complexity of social phenomena (Weber, $1986^{33}$; Ricolfi, $1997^{34}$ ), "The psychological effects of the coronavirus on children's lives" cannot be considered scientific research due to the presence of the following limits (Altieri, $2011^{35}$ ). First, this online research doesn't allow verifying whether the parent who had two or more children filled in two questionnaires or one, summarizing the data that emerged from the behavior of the two (or more) children; it was not possible to check the context in which the assessment took place (noises, interruptions, presence of family members that may have caused disturbance during the compilation). Second, possible sampling errors because the profile of the Internet population is not superimposable on that of the population in general even though this aspect is evolving. Third, it was necessary to assume a certain skill in the use of devices (smartphone, tablet, computer) and the possession of an email, or Whatsapp/Facebook profile. As a result, many parents did not respond to the questionnaire because they lacked the necessary technological equipment or because they did not receive the link to access the online questionnaire. Fourth, the limited number of questions (twelve), their order and formulation do not allow detecting with absolute certainty the presence/absence of the behaviors that are the object of the research: Regression, Protest, Adaptation. Finally, and most importantly, several key variables have not been assessed such as the response of parents to the pandemic (which can obviously influence children's reactions); the psychophysical condition of children before the distressing situation; the quality of parentchild interaction before and during the pandemic; the presence of resilience factors.

\footnotetext{
${ }^{32}$ Palumbo M., Garbarino E. (2006). Ricerca sociale: metodo e tecniche. Franco Angeli, Milano.

${ }^{33}$ Weber M. (1986). Il metodo delle scienze storico-sociali. Einaudi, Torino.

${ }^{34}$ Ricolfi L. (1997). La ricerca qualitativa, NIS, Roma.

${ }^{35}$ Altieri L. (2011). Valutazione e partecipazione. Metodologia per una ricerca Interattiva e negoziale. Franco Angeli, Milano.
} 
Tables 1-12 and charts 1-12

Tab. 1. Answers to question $\mathbf{n} .01$ by age group.

\begin{tabular}{|c|c|c|}
\hline $\begin{array}{l}\text { Age groups } \\
\text { accepted for } \\
\text { the } \\
\text { research }\end{array}$ & $\begin{array}{l}\mathrm{N}^{\circ} \text { of completed } \\
\text { questionnaires }\end{array}$ & $\begin{array}{l}\text { Has your son/daughter asked to sleep in his/her parents' bed in the last week? } \\
\text { (This question is only answered if the child has acquired the competence to } \\
\text { sleep alone in his or her room before the Covid-19 emergency). }\end{array}$ \\
\hline 4 & 920 & \begin{tabular}{|ll} 
YES 263 & $28.59 \%$ \\
NO 647 & $70.33 \%$ \\
N/A 10 & $1.09 \%$
\end{tabular} \\
\hline 5 & 869 & \begin{tabular}{|lc|} 
YES 232 & \multicolumn{1}{c}{$26.7 \%$} \\
NO 626 & $72.04 \%$ \\
N/A 11 & $1.27 \%$ \\
\end{tabular} \\
\hline 6 & 857 & \begin{tabular}{|ll} 
YES 236 & $27.54 \%$ \\
NO 612 & $71.41 \%$ \\
N/A 9 & $1.05 \%$ \\
\end{tabular} \\
\hline 7 & 794 & \begin{tabular}{|ll} 
YES 220 & $27.71 \%$ \\
NO 570 & $71.79 \%$ \\
N/A 4 & $0.5 \%$ \\
\end{tabular} \\
\hline 8 & 895 & \begin{tabular}{|ll} 
YES 214 & $23.91 \%$ \\
NO 674 & $75.31 \%$ \\
N/A 7 & $0.78 \%$ \\
\end{tabular} \\
\hline 9 & 908 & \begin{tabular}{|ll} 
YES 231 & \multicolumn{1}{c}{$25.44 \%$} \\
NO 667 & $73.46 \%$ \\
N/A 10 & $1.1 \%$ \\
\end{tabular} \\
\hline 10 & 746 & \begin{tabular}{|ll} 
YES 190 & $25.47 \%$ \\
NO 553 & $74.13 \%$ \\
N/A 3 & $0.4 \%$ \\
\end{tabular} \\
\hline TOTAL & 5989 & \\
\hline
\end{tabular}

Chart 01. Average between positive and negative responses to question $\mathrm{n} .01$.

\begin{tabular}{|l|r|}
\hline YES & $26.48 \%$ \\
\hline NO & $72.62 \%$ \\
\hline N/A & $0.90 \%$ \\
\hline
\end{tabular}

\section{Question 1}

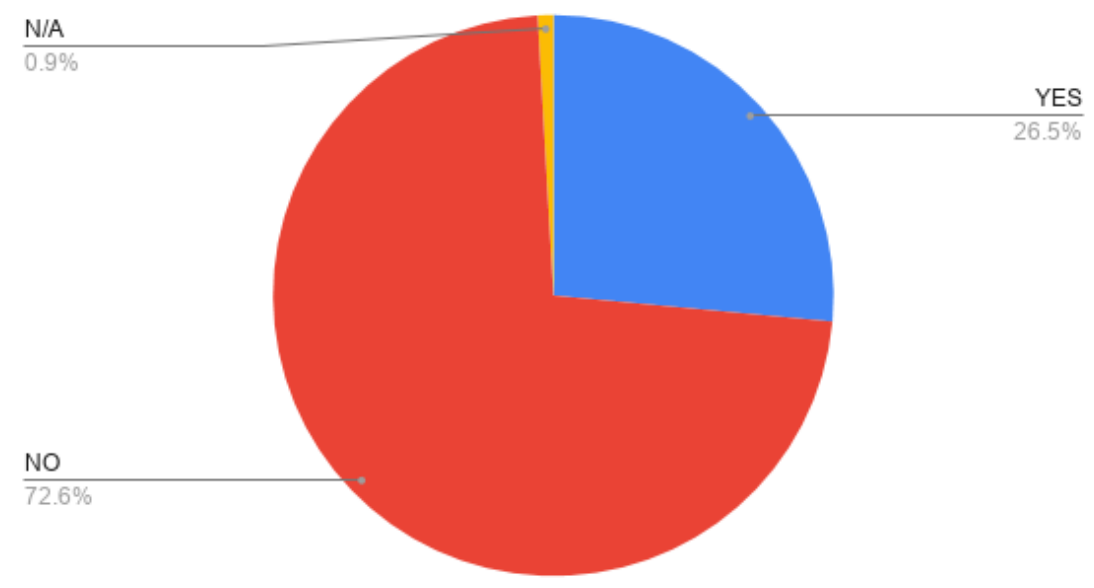


Tab. 2. Answers to question $\mathbf{n} .02$ by age group.

\begin{tabular}{|c|c|c|}
\hline $\begin{array}{l}\text { Age groups } \\
\text { accepted for the } \\
\text { research }\end{array}$ & $\mathrm{N}^{\circ}$ of completed Questionnaires & $\begin{array}{l}\text { Has your son/daughter been wetting the bed again in the } \\
\text { last week? }\end{array}$ \\
\hline 4 & 920 & $\begin{array}{|ll|}\text { YES 50 } & 5.43 \% \\
\text { NO } 869 & 94.46 \% \\
\text { N/A 1 } & 0.11 \%\end{array}$ \\
\hline 5 & 869 & $\begin{array}{ll}\text { YES 43 } & 4.95 \% \\
\text { NO } 826 & 95.05 \% \\
\text { N/A } & 00 \% \\
\end{array}$ \\
\hline 6 & 857 & $\begin{array}{|ll|}\text { YES 26 } & 3.03 \% \\
\text { NO 831 } & 96.97 \% \\
\text { N/A } & 0.0 \% \\
\end{array}$ \\
\hline 7 & 794 & \begin{tabular}{|ll|} 
YES 17 & \multicolumn{1}{c}{$2.14 \%$} \\
NO 775 & $97.61 \%$ \\
N/A 2 & $0.25 \%$ \\
\end{tabular} \\
\hline 8 & 895 & $\begin{array}{ll}\text { YES 16 } & 1.79 \% \\
\text { NO } 878 & 98.1 \% \\
\text { N/A 1 } & 0.11 \% \\
\end{array}$ \\
\hline 9 & 908 & $\begin{array}{ll}\text { YES 12 } & 1.32 \% \\
\text { NO 894 } & 98.46 \% \\
\text { N/A 2 } & 0.22 \% \\
\end{array}$ \\
\hline 10 & 746 & $\begin{array}{|lc|}\text { YES 6 } & 0.8 \% \\
\text { NO } 740 & 99.2 \% \\
\text { N/A } & 00 \% \\
\end{array}$ \\
\hline TOTAL & 5989 & \\
\hline
\end{tabular}

Chart 02. Average between positive and negative responses to question n. 02.

\begin{tabular}{|l|r|}
\hline YES & $2.84 \%$ \\
\hline NO & $97.06 \%$ \\
\hline N/A & $0.10 \%$ \\
\hline
\end{tabular}

\section{Question 2}

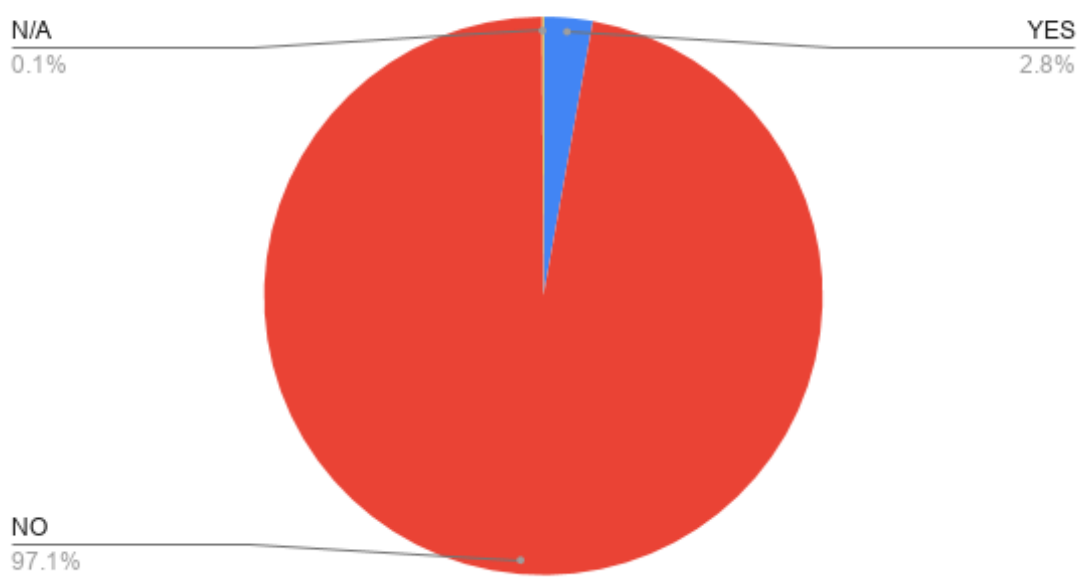


Tab. 3. Answers to question $\mathbf{n} .03$ by age group.

\begin{tabular}{|c|c|c|}
\hline $\begin{array}{l}\text { Age groups } \\
\text { accepted for the }\end{array}$ & $\begin{array}{l}\mathrm{N}^{\circ} \text { of completed } \\
\text { questionnaires }\end{array}$ & $\begin{array}{l}\text { In the last week, has your son/daughter experienced a general } \\
\text { deterioration in their vocabulary? }\end{array}$ \\
\hline 4 & 920 & $\begin{array}{|lc|}\text { YES 68 } & 7.39 \% \\
\text { NO 851 } & 92.5 \% \\
\text { N/A 1 } & 0.11 \% \\
\end{array}$ \\
\hline 5 & 869 & $\begin{array}{|lr|}\text { YES 47 } & 5.41 \% \\
\text { NO 822 } & 94.59 \% \\
\text { N/A } & 00 \%\end{array}$ \\
\hline 6 & 857 & $\begin{array}{|ll|}\text { YES 51 } & 5.95 \% \\
\text { NO } 806 & 94.05 \% \\
\text { N/A } & 00 \% \\
\end{array}$ \\
\hline 7 & 794 & $\begin{array}{ll}\text { YES 37 } & 4.66 \% \\
\text { NO 755 } & 95.09 \% \\
\text { N/A 2 } & 0.25 \%\end{array}$ \\
\hline 8 & 895 & $\begin{array}{|lr|}\text { YES 44 } & 4.92 \% \\
\text { NO 850 } & 94.97 \% \\
\text { N/A 1 } & 0.11 \%\end{array}$ \\
\hline 9 & 908 & $\begin{array}{|lr|}\text { YES 42 } & 4.63 \% \\
\text { NO } 864 & 95.15 \% \\
\text { N/A 2 } & 0.22 \%\end{array}$ \\
\hline 10 & 746 & $\begin{array}{ll}\text { YES } 39 & 5.23 \% \\
\text { NO } 707 & 94.77 \% \\
\text { N/A } & 00 \%\end{array}$ \\
\hline TOTAL & 5989 & \\
\hline
\end{tabular}

Chart 03. Average between positive and negative responses to question $\mathrm{n} .03$.

\begin{tabular}{|l|r|}
\hline YES & $5.48 \%$ \\
\hline NO & $94.42 \%$ \\
\hline N/A & $0.10 \%$ \\
\hline
\end{tabular}

\section{Question 3}

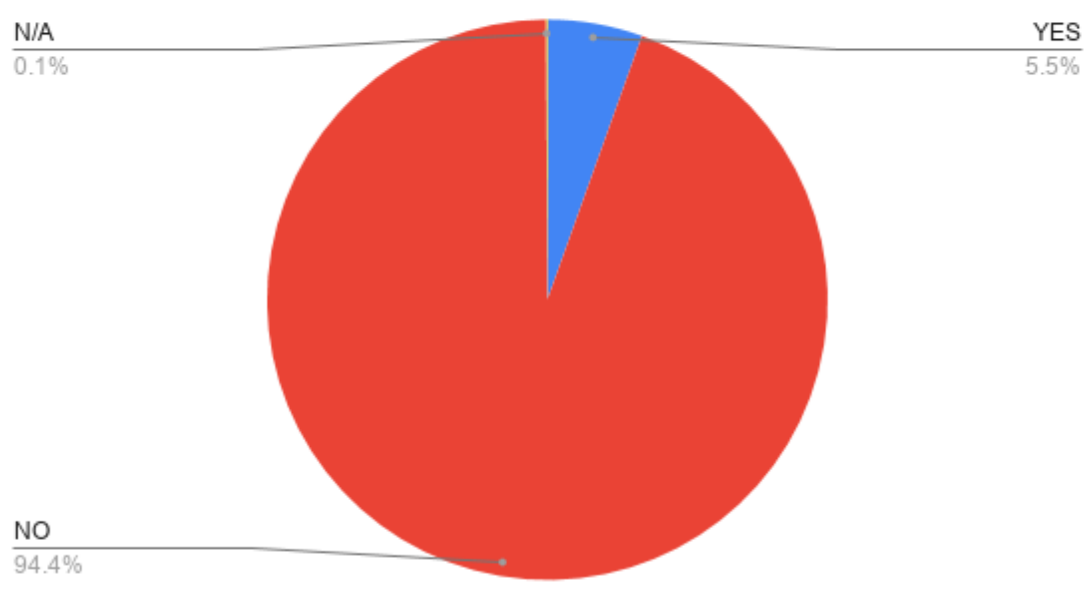


Tab. 4. Answers to question $n .04$ by age group.

\begin{tabular}{|c|c|c|}
\hline $\begin{array}{l}\text { Age groups accepted } \\
\text { for the }\end{array}$ & $\begin{array}{l}\mathbf{N}^{\circ} \text { of completed } \\
\text { questionnaires }\end{array}$ & $\begin{array}{l}\text { In the last week, has your son expressed fears that he/she } \\
\text { didn't have before? }\end{array}$ \\
\hline 4 & 920 & $\begin{array}{|ll|}\text { YES 160 } & 17.39 \% \\
\text { NO 759 } & 82.5 \% \\
\text { N/A 1 } & 0.11 \% \\
\end{array}$ \\
\hline 5 & 869 & $\begin{array}{|lr|}\text { YES 155 } & 17.84 \% \\
\text { NO } 714 & 82.16 \% \\
\text { N/A } & 00 \%\end{array}$ \\
\hline 6 & 857 & $\begin{array}{|ll|}\text { YES 155 } & 18.09 \% \\
\text { NO } 702 & 81.91 \% \\
\text { N/A } & 00 \% \\
\end{array}$ \\
\hline 7 & 794 & $\begin{array}{ll}\text { YES 141 } & 17.76 \% \\
\text { NO } 651 & 81.99 \% \\
\text { N/A 2 } & 0.25 \%\end{array}$ \\
\hline 8 & 895 & $\begin{array}{|ll|}\text { YES 160 } & 17.88 \% \\
\text { NO } 734 & 82.01 \% \\
\text { N/A 1 } & 0.11 \%\end{array}$ \\
\hline 9 & 908 & $\begin{array}{l}\text { YES } 162 \quad 17.84 \% \\
\text { NO } 744 \quad 81.94 \% \\
\text { N/A } 2 \quad 0.22 \%\end{array}$ \\
\hline 10 & 746 & $\begin{array}{l}\text { YES } 155 \quad 20.78 \% \\
\text { NO } 591 \quad 79.22 \% \\
\text { N/A } 00 \%\end{array}$ \\
\hline TOTAL & 5989 & \\
\hline
\end{tabular}

Chart 04. Average between positive and negative responses to question n. 04.

\begin{tabular}{|l|r|}
\hline YES & $18.17 \%$ \\
\hline NO & $81.73 \%$ \\
\hline N/A & $0.10 \%$ \\
\hline
\end{tabular}

\section{Question 4}

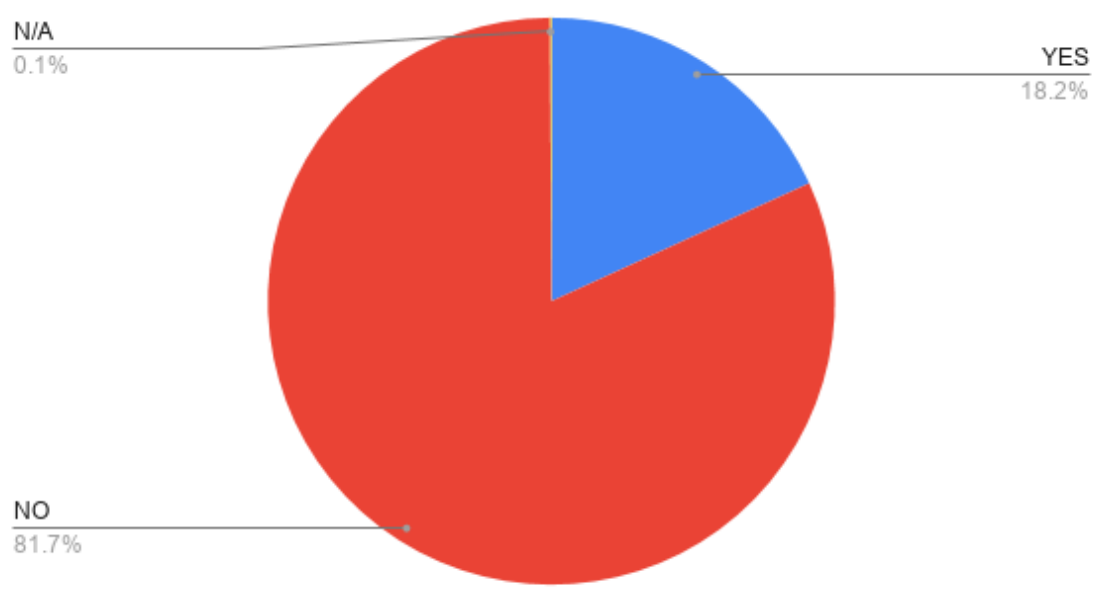


Tab. 5. Answers to question $\mathrm{n} .05$ by age group.

\begin{tabular}{|c|c|c|}
\hline $\begin{array}{l}\text { Age groups } \\
\text { accepted for the } \\
\text { research }\end{array}$ & $\begin{array}{l}\mathrm{N}^{\circ} \text { of completed } \\
\text { questionnaires }\end{array}$ & $\begin{array}{l}\text { 5. In the last week, did your child show more irritability (intolerance } \\
\text { to rules, caprices, excessive demands)? }\end{array}$ \\
\hline 4 & 920 & \begin{tabular}{|lr} 
YES 587 & $63.8 \%$ \\
NO 332 & $36.09 \%$ \\
N/A 1 & $0.11 \%$
\end{tabular} \\
\hline 5 & 869 & $\begin{array}{ll}\text { YES } 518 & 59.61 \% \\
\text { NO } 351 \quad 40.39 \% \\
\text { N/A } \quad 00 \%\end{array}$ \\
\hline 6 & 857 & $\begin{array}{ll}\text { YES } 470 & 54.84 \% \\
\text { NO } 387 & 45.16 \% \\
\text { N/A } & 0\end{array}$ \\
\hline 7 & 794 & $\begin{array}{ll}\text { YES } 418 & 52.64 \% \\
\text { NO } 374 & 47.1 \% \\
\text { N/A 2 } & 0.25 \%\end{array}$ \\
\hline 8 & 895 & $\begin{array}{l}\text { YES } 449 \quad 50.17 \% \\
\text { NO } 445 \quad 49.72 \% \\
\text { N/A } 1 \quad 0.11 \%\end{array}$ \\
\hline 9 & 908 & $\begin{array}{|lr|}\text { YES 413 } & 45.48 \% \\
\text { NO } 493 \quad 54.3 \% \\
\text { N/A 2 } & 0.22 \%\end{array}$ \\
\hline 10 & 746 & $\begin{array}{ll}\text { YES } 351 & 47.05 \% \\
\text { NO } 395 & 52.95 \% \\
\text { N/A } 0 & 0 \% \\
\end{array}$ \\
\hline TOTAL & 5989 & \\
\hline
\end{tabular}

Chart 05. Average between positive and negative responses to question n. 05 .

\begin{tabular}{|l|r|}
\hline YES & $53.53 \%$ \\
\hline NO & $46.37 \%$ \\
\hline N/A & $0.10 \%$ \\
\hline
\end{tabular}

\section{Question 5}

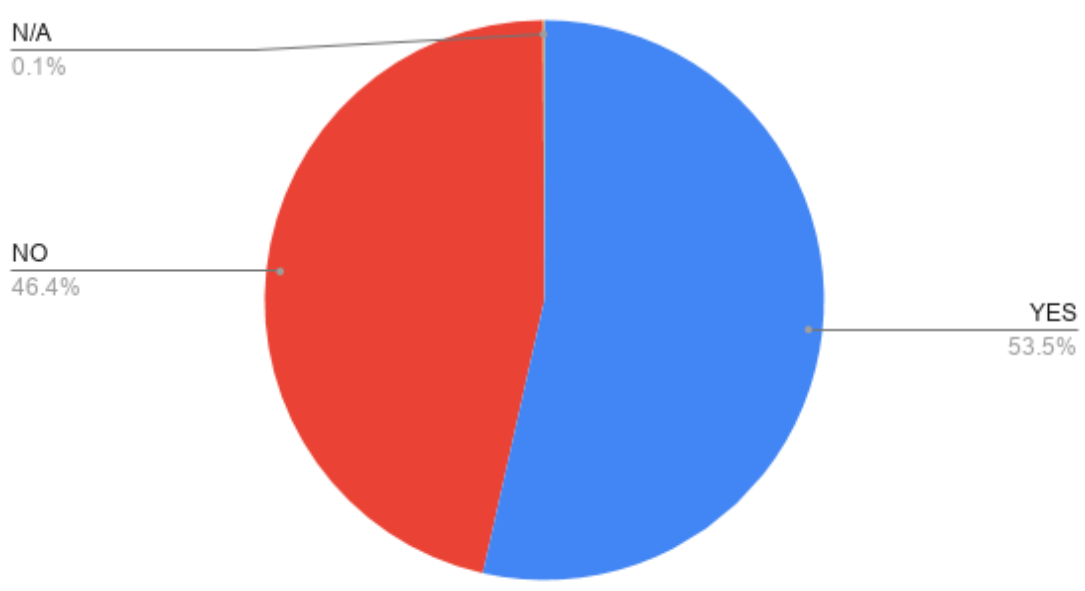


Tab. 6. Answers to question $\mathrm{n} .06$ by age group.

\begin{tabular}{|c|c|c|}
\hline $\begin{array}{l}\text { Age groups } \\
\text { accepted for the } \\
\text { research }\end{array}$ & $\begin{array}{l}\mathrm{N}^{\circ} \text { of completed } \\
\text { questionnaires }\end{array}$ & $\begin{array}{l}\text { 6. Over the last week, has your son/daughter experienced any } \\
\text { mood swings that you hadn't noticed before? }\end{array}$ \\
\hline 4 & 920 & $\begin{array}{ll}\text { YES } 229 & 24.89 \% \\
\text { NO } 690 & 75 \% \\
\text { N/A 1 } & 0.11 \%\end{array}$ \\
\hline 5 & 869 & $\begin{array}{ll}\text { YES } 183 & 21.06 \% \\
\text { NO } 686 & 78.94 \% \\
\text { N/A } \quad 00 \%\end{array}$ \\
\hline 6 & 857 & $\begin{array}{ll}\text { YES } 168 & 19.6 \% \\
\text { NO } 689 \quad 80.4 \% \\
\text { N/A } \quad 00 \% \\
\end{array}$ \\
\hline 7 & 794 & $\begin{array}{l}\text { YES } 154 \quad 19.4 \% \\
\text { NO } 638 \quad 80.35 \% \\
\text { N/A } 2 \quad 0.25 \%\end{array}$ \\
\hline 8 & 895 & $\begin{array}{l}\text { YES } 194 \quad 21.68 \% \\
\text { NO } 700 \quad 78.21 \% \\
\text { N/A } 1 \quad 0.11 \%\end{array}$ \\
\hline 9 & 908 & $\begin{array}{|lc|}\text { YES } 168 & 18.5 \% \\
\text { NO } 738 \quad 81.28 \% \\
\text { N/A 2 } & 0.22 \% \\
\end{array}$ \\
\hline 10 & 746 & $\begin{array}{ll}\text { YES } 172 & 23.06 \% \\
\text { NO } 574 \quad 76.94 \% \\
\text { N/A } 00 \%\end{array}$ \\
\hline TOTAL & 5989 & \\
\hline
\end{tabular}

Chart 06. Average between positive and negative responses to question $\mathrm{n} .06$.

\begin{tabular}{|l|r|}
\hline YES & $21.17 \%$ \\
\hline NO & $78.73 \%$ \\
\hline N/A & $0.10 \%$ \\
\hline
\end{tabular}

\section{Question 6}

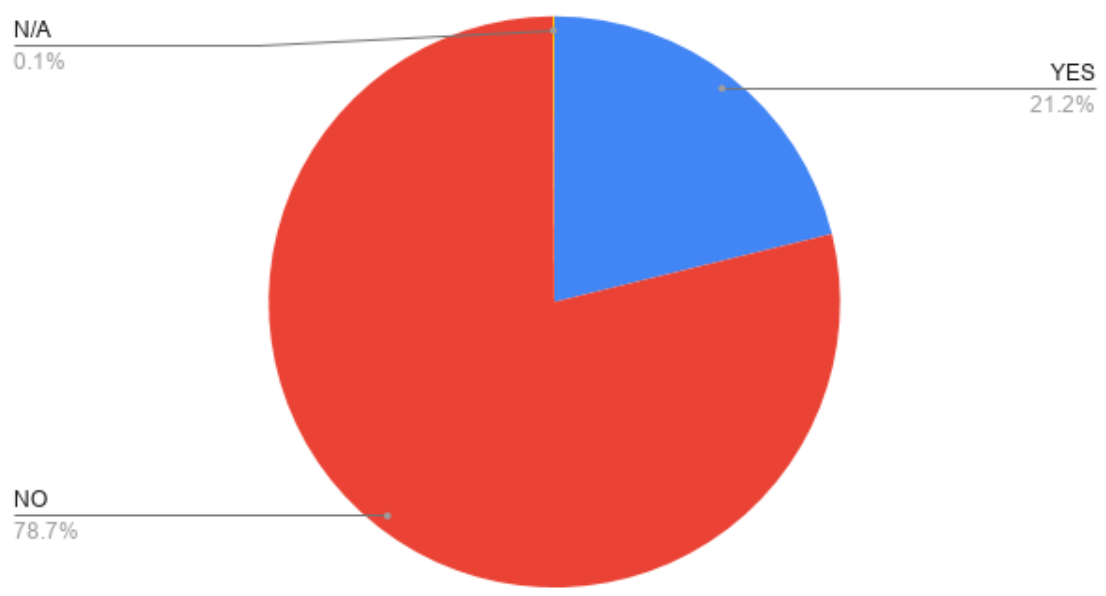


Tab. 7. Answers to question $\mathbf{n} .07$ by age group.

\begin{tabular}{|c|c|c|}
\hline $\begin{array}{l}\text { Age groups } \\
\text { accepted for the } \\
\text { research }\end{array}$ & $\begin{array}{l}\mathrm{N}^{\circ} \text { of completed } \\
\text { questionnaires }\end{array}$ & $\begin{array}{l}\text { 7. In the last week, did your child have sleep problems that you had not } \\
\text { observed before (difficulty falling asleep, agitation during sleep, frequent } \\
\text { awakenings)? }\end{array}$ \\
\hline 4 & 920 & \begin{tabular}{|ll} 
YES 188 & $20.43 \%$ \\
NO 731 & $79.46 \%$ \\
N/A 1 & $0.11 \%$
\end{tabular} \\
\hline 5 & 869 & $\begin{array}{ll}\text { YES } 165 & 18.99 \% \\
\text { NO } 704 & 81.01 \% \\
\text { N/A } & 00 \%\end{array}$ \\
\hline 6 & 857 & \begin{tabular}{|lr} 
YES 161 & $18.79 \%$ \\
NO 696 & $81.21 \%$ \\
N/A & $00 \%$ \\
\end{tabular} \\
\hline 7 & 794 & \begin{tabular}{|ll} 
YES 151 & $19.02 \%$ \\
NO 641 & $80.73 \%$ \\
N/A 2 & $0.25 \%$ \\
\end{tabular} \\
\hline 8 & 895 & $\begin{array}{l}\text { YES } 192 \quad 21.45 \% \\
\text { NO } 702 \quad 78.44 \% \\
\text { N/A } 1 \quad 0.11 \%\end{array}$ \\
\hline 9 & 908 & $\begin{array}{l}\text { YES } 159 \quad 17.51 \% \\
\text { NO } 74782.27 \% \\
\text { N/A } 2 \quad 0.22 \% \\
\end{array}$ \\
\hline 10 & 746 & \begin{tabular}{|lr} 
YES 181 & $24.26 \%$ \\
NO 565 & $75.74 \%$ \\
N/A $\quad 00 \%$ \\
\end{tabular} \\
\hline TOTAL & 5989 & \\
\hline
\end{tabular}

Chart 07. Average between positive and negative responses to question n. 07.

\begin{tabular}{|l|r|}
\hline YES & $19.99 \%$ \\
\hline NO & $79.91 \%$ \\
\hline N/A & $0.10 \%$ \\
\hline
\end{tabular}

\section{Question 7}

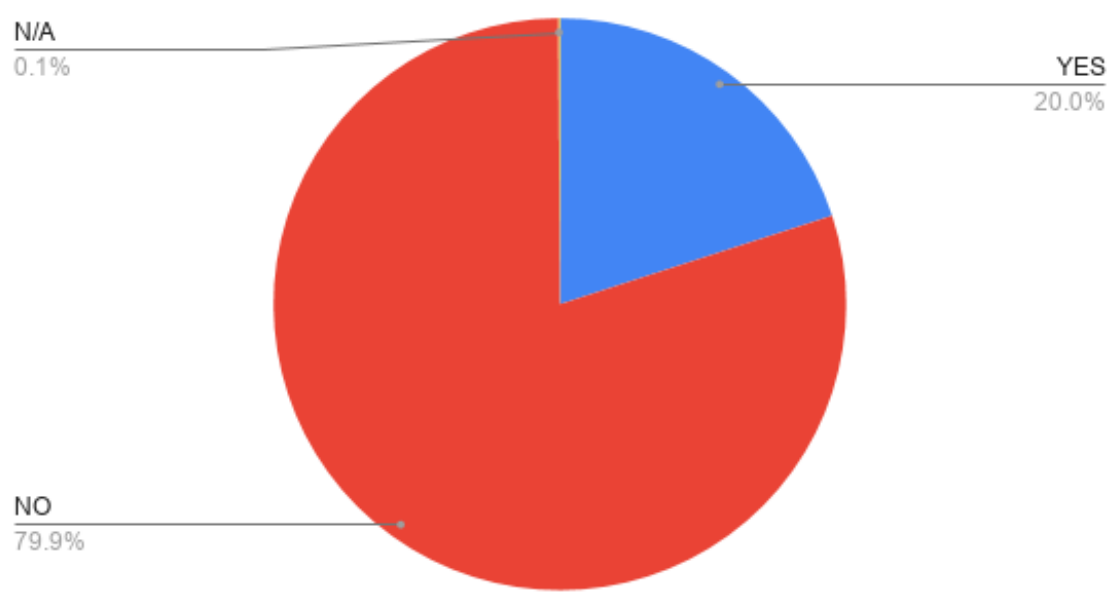


Tab. 8. Answers to question $\mathrm{n} .08$ by age group.

\begin{tabular}{|c|c|c|}
\hline $\begin{array}{l}\text { Age groups } \\
\text { accepted for the } \\
\text { research }\end{array}$ & $\begin{array}{l}\mathrm{N}^{\circ} \text { of completed } \\
\text { questionnaires }\end{array}$ & $\begin{array}{l}\text { 8. Has your child been nervous about the pandemic in the last week (when } \\
\text { confronted with messages coming from parents or TV about the } \\
\text { coronavirus; or because of restrictions)? }\end{array}$ \\
\hline 4 & 920 & $\begin{array}{|ll|}\text { YES } 232 & 25.22 \% \\
\text { NO } 687 & 74.67 \% \\
\text { N/A } 1 & 0.11 \%\end{array}$ \\
\hline 5 & 869 & \begin{tabular}{|ll} 
YES 261 & $30.03 \%$ \\
NO 608 & $69.97 \%$ \\
N/A $\quad 00 \%$
\end{tabular} \\
\hline 6 & 857 & $\begin{array}{l}\text { YES } 278 \quad 32.44 \% \\
\text { NO } 57967.56 \% \\
\text { N/A } \quad 00 \%\end{array}$ \\
\hline 7 & 794 & $\begin{array}{l}\text { YES } 287 \quad 36.15 \% \\
\text { NO } 505 \quad 63.6 \% \\
\text { N/A } 2 \quad 0.25 \%\end{array}$ \\
\hline 8 & 895 & \begin{tabular}{|ll} 
YES 349 & $38.99 \%$ \\
NO 545 & $60.89 \%$ \\
N/A $1 \quad 0.11 \%$ \\
\end{tabular} \\
\hline 9 & 908 & \begin{tabular}{|ll} 
YES 357 & $39.32 \%$ \\
NO 549 & $60.46 \%$ \\
N/A 2 & $0.22 \%$
\end{tabular} \\
\hline 10 & 746 & \begin{tabular}{|l} 
YES $28838.61 \%$ \\
NO $458 \quad 61.39 \%$ \\
N/A $\quad 00 \%$ \\
\end{tabular} \\
\hline TOTAL & 5989 & \\
\hline
\end{tabular}

Chart 08. Average between positive and negative responses to question $\mathrm{n} .08$.

\begin{tabular}{|l|r|}
\hline YES & $34.26 \%$ \\
\hline NO & $65.64 \%$ \\
\hline N/A & $0.10 \%$ \\
\hline
\end{tabular}

\section{Question 8}

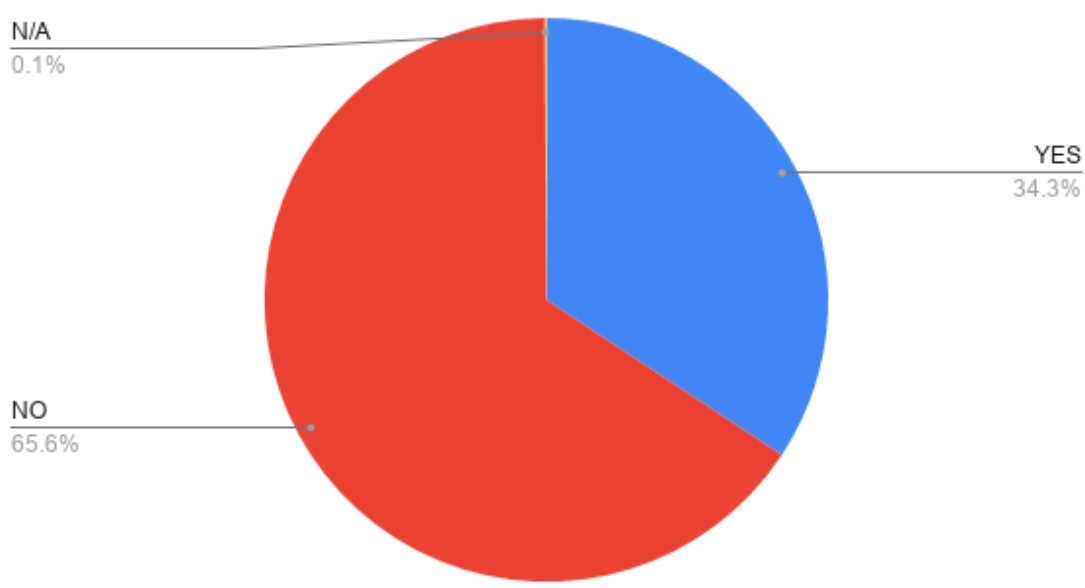


Tab. 9. Answers to question $\mathrm{n} .09$ by age group.

\begin{tabular}{|c|c|c|}
\hline $\begin{array}{l}\text { Age groups accepted for } \\
\text { the } \\
\text { research }\end{array}$ & $\begin{array}{l}\mathbf{N}^{\circ} \text { of completed } \\
\text { questionnaires }\end{array}$ & $\begin{array}{l}\text { 9. In the last week, has your son seemed calmer and } \\
\text { calmer to you? }\end{array}$ \\
\hline 4 & 920 & $\begin{array}{ll}\text { YES } 245 & 26.63 \% \\
\text { NO } 674 & 73.26 \% \\
\text { N/A } 1 & 0.11 \%\end{array}$ \\
\hline 5 & 869 & $\begin{array}{|ll|}\text { YES } 257 & 29.57 \% \\
\text { NO } 612 & 70.43 \% \\
\text { N/A } & 0.0 \%\end{array}$ \\
\hline 6 & 857 & $\begin{array}{|ll|}\text { YES 267 } & 31.16 \% \\
\text { NO 590 } & 68.84 \% \\
\text { N/A } & 00 \% \\
\end{array}$ \\
\hline 7 & 794 & $\begin{array}{|lr|}\text { YES 233 } & 29.35 \% \\
\text { NO 559 } & 70.4 \% \\
\text { N/A 2 } & 0.25 \% \\
\end{array}$ \\
\hline 8 & 895 & \begin{tabular}{|ll} 
YES 313 & $34.97 \%$ \\
NO 581 & $64.92 \%$ \\
N/A 1 & $0.11 \%$
\end{tabular} \\
\hline 9 & 908 & \begin{tabular}{|ll} 
YES 321 & $35.35 \%$ \\
NO 585 & $64.43 \%$ \\
N/A 2 & $0.22 \%$ \\
\end{tabular} \\
\hline 10 & 746 & \begin{tabular}{|ll} 
YES 270 & $36.19 \%$ \\
NO 476 & $63.81 \%$ \\
N/A & $00 \%$ \\
\end{tabular} \\
\hline TOTAL & 5989 & \\
\hline
\end{tabular}

Chart 09. Average between positive and negative responses to question n. 09 .

\begin{tabular}{|l|r|}
\hline YES & $31.83 \%$ \\
\hline NO & $68.07 \%$ \\
\hline N/A & $0.10 \%$ \\
\hline
\end{tabular}

\section{Question 9}

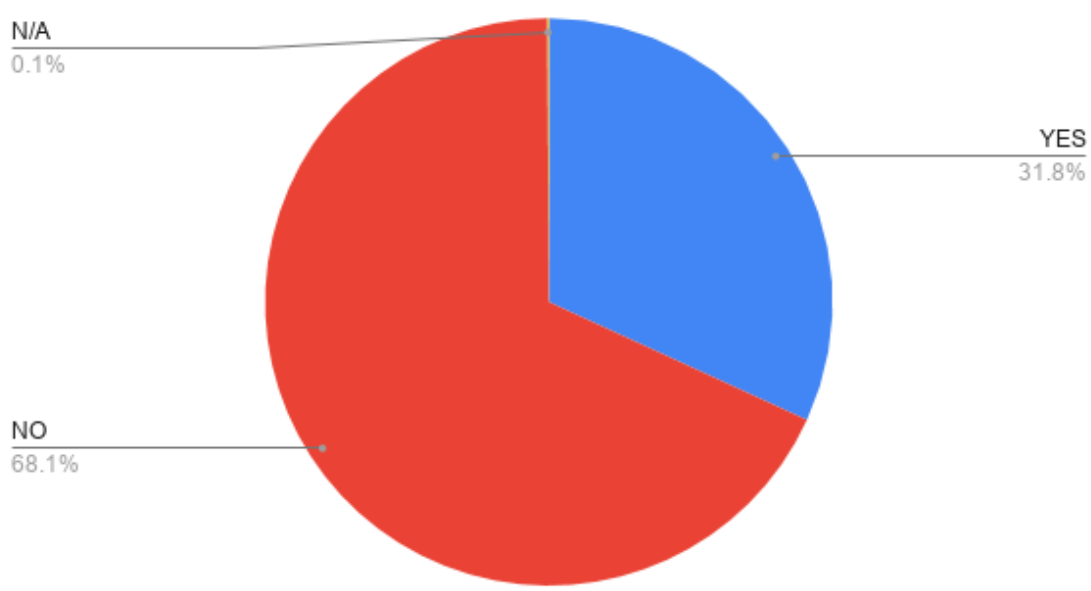


Tab. 10. Answers to question $\mathbf{n} .10$ by age group.

\begin{tabular}{|c|c|c|}
\hline $\begin{array}{l}\text { Age groups accepted for } \\
\text { the } \\
\text { research }\end{array}$ & $\begin{array}{l}\mathrm{N}^{\circ} \text { of completed } \\
\text { questionnaires }\end{array}$ & $\begin{array}{l}\text { 10. Did your son seem wiser and more thoughtful in the } \\
\text { last week? }\end{array}$ \\
\hline 4 & 920 & $\begin{array}{ll}\text { YES 404 } & 43.91 \% \\
\text { NO } 515 & 55.98 \% \\
\text { N/A } 1 & 0.11 \%\end{array}$ \\
\hline 5 & 869 & $\begin{array}{ll}\text { YES 416 } & 47.87 \% \\
\text { NO 453 } & 52.13 \% \\
\text { N/A } & 00 \%\end{array}$ \\
\hline 6 & 857 & $\begin{array}{ll}\text { YES 438 } & 51.11 \% \\
\text { NO 419 } & 48.89 \% \\
\text { N/A } & 00 \%\end{array}$ \\
\hline 7 & 794 & $\begin{array}{ll}\text { YES 369 } & 46.47 \% \\
\text { NO 423 } & 53.27 \% \\
\text { N/A 2 } & 0.25 \%\end{array}$ \\
\hline 8 & 895 & $\begin{array}{ll}\text { YES 459 } & 51.28 \% \\
\text { NO 435 } & 48.6 \% \\
\text { N/A 1 } & 0.11 \%\end{array}$ \\
\hline 9 & 908 & $\begin{array}{ll}486 & 53.52 \% \\
\text { NO } 420 & 46.26 \% \\
\text { N/A 2 } & 0.22 \%\end{array}$ \\
\hline 10 & 746 & $\begin{array}{ll}397 & 53.22 \% \\
\text { NO } 349 & 46.78 \% \\
\text { N/A } & 00 \%\end{array}$ \\
\hline TOTAL & 5989 & \\
\hline
\end{tabular}

Chart 10. Average between positive and negative responses to question $n .10$.

\begin{tabular}{|l|r|}
\hline YES & $49.57 \%$ \\
\hline NO & $50.33 \%$ \\
\hline N/A & $0.10 \%$ \\
\hline
\end{tabular}

\section{Question 10}

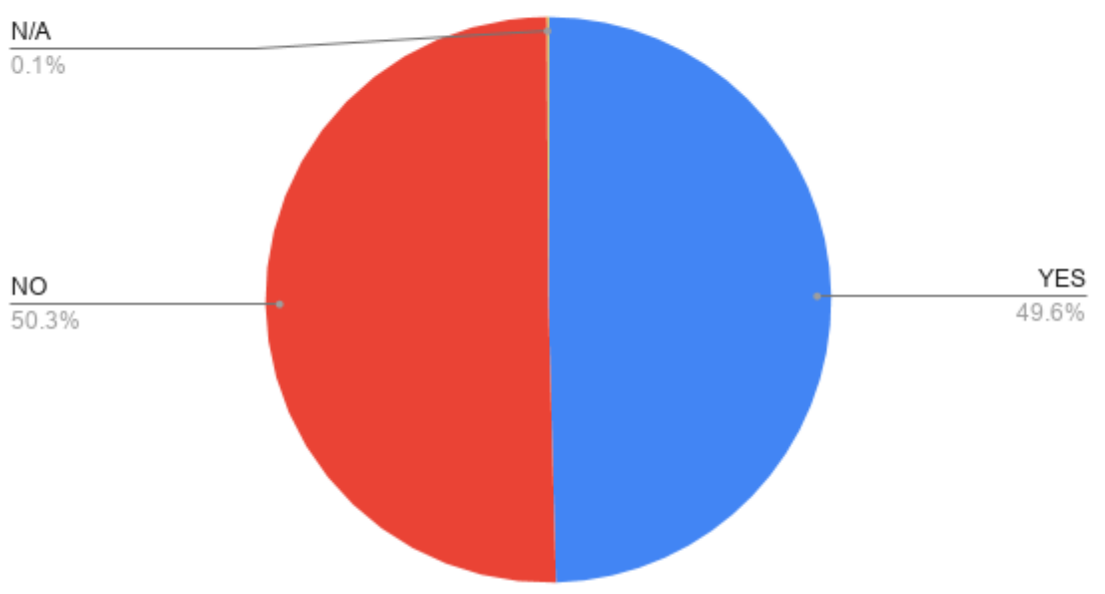


Tab. 11. Answers to question $\mathbf{n} .11$ by age group.

\begin{tabular}{|c|c|c|}
\hline $\begin{array}{l}\text { Age groups accepted } \\
\text { for the } \\
\text { research }\end{array}$ & $\begin{array}{l}\mathrm{N}^{\circ} \text { of completed } \\
\text { questionnaires }\end{array}$ & $\begin{array}{l}\text { 11. In the last week, did your son/daughter seem able to adapt } \\
\text { to the pandemic restrictions? }\end{array}$ \\
\hline 4 & 920 & $\begin{array}{ll}\text { YES 833 } & 90.54 \% \\
\text { NO 86 } & 9.35 \% \\
\text { N.R. 1 } & 0.11 \%\end{array}$ \\
\hline 5 & 869 & $\begin{array}{ll}\text { YES 812 } & 93.44 \% \\
\text { NO } 57 & 6.56 \% \\
\text { N/A } & 00 \%\end{array}$ \\
\hline 6 & 857 & $\begin{array}{ll}\text { YES 792 } & 92.42 \% \\
\text { NO 65 } & 7.58 \% \\
\text { N/A } & 00 \% \\
\end{array}$ \\
\hline 7 & 794 & $\begin{array}{ll}\text { YES 744 } & 93.7 \% \\
\text { NO 48 } & 6.05 \% \\
\text { N/A 2 } & 0.25 \%\end{array}$ \\
\hline 8 & 895 & $\begin{array}{ll}\text { YES 830 } & 92.74 \% \\
\text { NO 64 } & 7.15 \% \\
\text { N/A 1 } & 0.11 \%\end{array}$ \\
\hline 9 & 908 & $\begin{array}{ll}\text { YES 841 } & 92.62 \% \\
\text { NO 65 } & 7.16 \% \\
\text { N/A 2 } & 0.22 \%\end{array}$ \\
\hline 10 & 746 & $\begin{array}{l}\text { YES } 692 \quad 92.76 \% \\
\text { NO } 54 \quad 7.24 \% \\
\text { N/A } 00 \%\end{array}$ \\
\hline TOTAL & 5989 & \\
\hline
\end{tabular}

Chart 11. Average between positive and negative responses to question $n .11$.

\begin{tabular}{|l|r|}
\hline YES & $92.57 \%$ \\
\hline NO & $7.33 \%$ \\
\hline N/A & $0.10 \%$ \\
\hline
\end{tabular}

Question 11

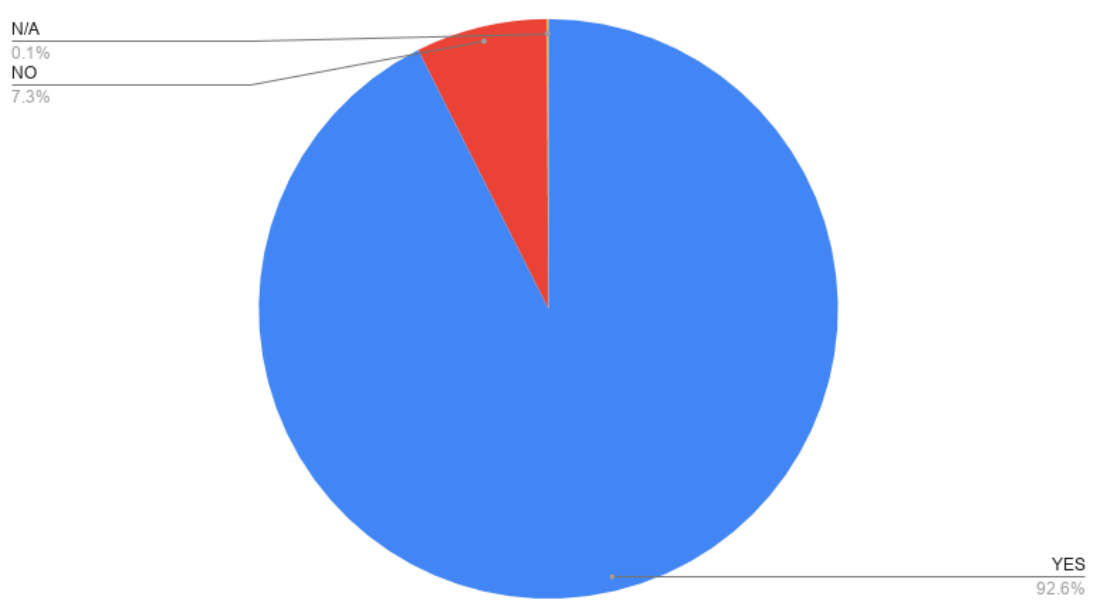


Tab. 12. Answers to question $\mathrm{n} .12$ by age group.

\begin{tabular}{|c|c|c|}
\hline $\begin{array}{l}\text { Age groups } \\
\text { accepted for the }\end{array}$ & $\begin{array}{l}\mathrm{N}^{\circ} \text { of completed } \\
\text { questionnaires }\end{array}$ & $\begin{array}{l}\text { 12. In the last week, did your son/daughter seem lazier than he was } \\
\text { before the pandemic (playing, studying, gaming, etc.)? }\end{array}$ \\
\hline 4 & 920 & $\begin{array}{|lc|}\text { YES 311 } & 33.8 \% \\
\text { NO 608 } & 66.09 \% \\
\text { N/A 1 } & 0.11 \%\end{array}$ \\
\hline 5 & 869 & $\begin{array}{|lr|}\text { YES 316 } & 36.36 \% \\
\text { NO 553 } & 63.64 \% \\
\text { N/A } & 00 \%\end{array}$ \\
\hline 6 & 857 & $\begin{array}{|ll|}\text { YES 379 } & 44.22 \% \\
\text { NO 478 } & 55.78 \% \\
\text { N/A } & 00 \% \\
\end{array}$ \\
\hline 7 & 794 & $\begin{array}{ll}\text { YES 361 } & 45.47 \% \\
\text { NO } 431 & 54.28 \% \\
\text { N/A 2 } & 0.25 \%\end{array}$ \\
\hline 8 & 895 & $\begin{array}{|lr|}\text { YES 424 } & 47.37 \% \\
\text { NO } 470 & 52.51 \% \\
\text { N/A } 1 & 0.11 \%\end{array}$ \\
\hline 9 & 908 & $\begin{array}{l}\text { YES } 410 \quad 45.15 \% \\
\text { NO } 49654.63 \% \\
\text { N/A } 2 \quad 0.22 \%\end{array}$ \\
\hline 10 & 746 & $\begin{array}{l}\text { YES } 390 \quad 52.28 \% \\
\text { NO } 35647.72 \% \\
\text { N/A } \quad 00 \%\end{array}$ \\
\hline TOTAL & 5989 & \\
\hline
\end{tabular}

Chart 12. Average between positive and negative responses to question $n .12$.

\begin{tabular}{|l|r|}
\hline YES & $43.26 \%$ \\
\hline NO & $56.64 \%$ \\
\hline N/A. & $0.10 \%$ \\
\hline
\end{tabular}

\section{Question 12}

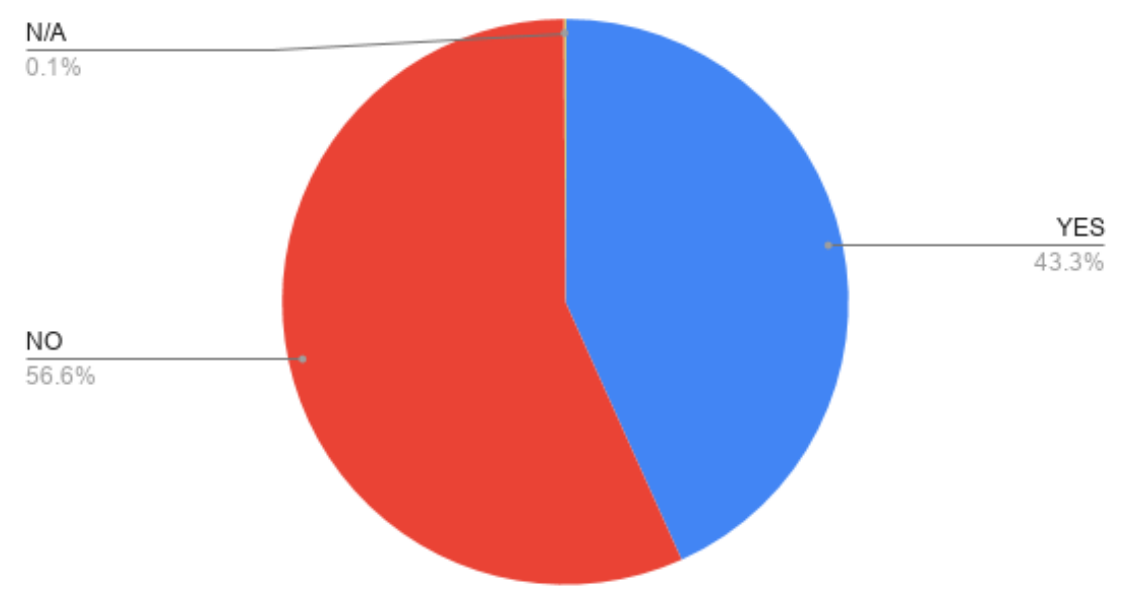

